\title{
TRADUÇÃO E ESTUDO DE DUAS CRÔNICAS DE JOSÉ ALDEMIR
}

\author{
Esteban Reyes Celedón (UFAM) ${ }^{1}$
}

RESUMO: A crônica moderna ou crônica urbana, que nasceu no jornal, rapidamente evoluiu e, pelas suas qualidades estéticas (ou poéticas, para sermos menos germânicos), se tornou um gênero literário. Excluem-se, evidentemente, as crônicas sem qualidades estéticas, que não são poucas. Por tratar da cidade, da arquitetura, da urbanização, do espaço planejado, as chances de termos crônicas urbanas interessantes aumentam quando se trata de um autor que entende (além de literatura) do assunto, pode ser um arquiteto, urbanista ou geógrafo urbano. É o caso do cronista e professor da UFAM, José Aldemir de Oliveira, cronista, ha décadas, e especialista em Geografia Urbana, em Geografia Humana. Por este motivo, já faz muitos anos, que escolhemos este autor (e suas crônicas) para estudarmos. Nesta ocasião, levando em conta a requisição da chamada desta revista para o número 6, selecionamos duas crônicas, deste autor amazonense, que falam de três cidades espanholas, a saber, Madri, Salamanca e Barcelona. Nossa proposta é, além da tradução de ditas crônicas para o espanhol, fazermos uma análise e estudos das mesmas; faremos algumas considerações sobre a particularidade deste tipo de tradução e compartilharemos com o leitor alguns comentários que consideramos relevantes, fundamentando nossas escolhas de tradução em teóricos da tradução (como o brasileiro Paulo Henrique Britto), além de comentários informativos sobre alguns levantamentos expostos nas crônicas.

PALAVRAS-CHAVE: Crônicas urbanas; Crônicas da minha (C)idade; Crônicas de cidades espanholas; Tradução literária; José Aldemir de Oliveira.

RESUMEN: La crónica moderna o crónica urbana, que nació en el periódico, rápidamente evolucionó y, por sus cualidades estéticas (o poéticas, para ser menos germánicos), se convirtió en un género literario. Se excluyen, evidentemente, las crónicas sin cualidades estéticas, que no son pocas. Por tratar de la ciudad, de la arquitectura, de la urbanización, del espacio planeado, las posibilidades de tener crónicas urbanas interesantes aumentan cuando se trata de un autor que entiende (además de literatura) del asunto, puede ser un arquitecto, urbanista o geógrafo urbano. Es el caso del cronista y profesor de la UFAM, José Aldemir de Oliveira, cronista, hace décadas, y especialista en Geografía Urbana, en Geografía Humana. Por este motivo, ya hace muchos años, que elegimos a este autor (y sus crónicas) para estudiar. En esta ocasión, teniendo en cuenta la petición de la llamada de esta revista al número 6, seleccionamos dos crónicas, de este autor amazonense, que tratan de tres ciudades españolas, a saber, Madrid, Salamanca y Barcelona. Nuestra propuesta es, además de la traducción de dichas crónicas al español, hacer un análisis y estudios de las mismas; y en el caso de las crónicas, las reflexiones sobre la particularidad de este tipo de traducción y compartir con el lector algunos comentarios que consideramos relevantes, fundamentando nuestras opciones de traducción en teóricos de la traducción (como el brasileño Paulo Henrique Britto), además de comentarios informativos sobre algunos levantamientos expuestos en las crónicas.

PALABRAS-ClAVE: Crónicas urbanas; Crónicas de mi ciudad; Crónicas de ciudades españolas; Traducción literaria, José Aldemir de Oliveira.

1Doutor em Letras Neolatinas pela UFRJ (2007). Professor do curso de Letras - Língua e Literatura Espanhola e do Programa de Pós-graduação em Letras na UFAM. Pós-doutorado em Estudos da Tradução no PGET-UFSC (2018). Líder do Grupo de pesquisa A crônica brasileira: dilemas, paradoxos e soluções de um gênero moderno, UFAM. Também faz parte do Grupo de pesquisa Núcleo Quevedo Estudos Literários e Traduções do Século de Ouro, UFSC. 


\section{INTRODUÇÃO}

Nos últimos anos, tenho dedicado boa parte do meu tempo de estudo e pesquisa à tradução. A meu ver, uma das curiosidades dos estudos da tradução são os chamados mitos. Por exemplo, o mito de Babel, que vê a tradução quase como uma maldição divina. Já que as pessoas falam línguas diferentes e não se entendem, cabe ao tradutor fazer esse trabalho praticamente como um castigo divino, que, na melhor das hipóteses, seria uma cópia infiel (infidelidade que não deixa de ser um pecado) de um suposto original, que por ser humano, não é perfeito. Resumindo: a tradução seria um castigo e o tradutor um pecador.

Outro mito da tradução seria o da "ponte", a tradução seria aquela ponte que possibilita a união, o acesso, e a comunicação entre duas línguas e culturas diferentes. Trata-se de mais um mito, ou seja, não é verdade. O que constatamos no mundo real é que, na maioria das vezes, não passa de uma questão de poder: por um lado, as obras das chamadas "línguas dominantes" e de maior prestígio (seja cultural, científico, econômico ou mesmo militar) são traduzidas a "línguas menores" que se auto-enxergam como dominadas ou inferiores (seja em termos culturais, científicos, econômicos ou mesmo militar); por outro lado, raramente constatamos o movimento em sentido contrário, ou seja, obras escritas numa suposta "língua menor" traduzida para uma das chamadas "línguas dominantes". Isto é, a ponte da tradução praticamente só tem uma direção e sentido; uma ponte tão estreita que parece só ter uma via, ou não parece ponte.

Um dos objetivos deste trabalho é, na tentativa de mudar um pouco esta situação, traduzir duas crônicas de um autor amazonense, que escreve em português, para o espanhol. Mas, como queremos afirmar o trânsito nos dois sentidos desta nossa ponte literária e cultural, escolhemos duas crônicas que falam sobre cidades espanholas, visitadas por nosso Cronista alguns anos atrás.

Ou seja, se por um lado, o cronista nos presenteia, para nós que lemos português e que talvez nunca visitemos Europa, com uma particular descrição de cidades espanholas, por outro lado, ao traduzirmos para o espanhol essas crônicas, presenteamos, aos leitores da língua de Cervantes, com a descrição do olhar estrangeiro sobre essas cidades do velho continente, mais antigas do que qualquer cidade brasileira.

Antes de apresentarmos as duas crônicas na versão do autor, seguida da nossa proposta de tradução, faremos algumas considerações sobre a particularidade deste tipo de tradução e compartilharemos com o leitor alguns comentários que consideramos relevantes, fundamentando 
nossas escolhas de tradução, além de comentários informativos sobre alguns levantamentos expostos nas crônicas.

\section{CONSIDERAÇÕES SOBRE A TRADUÇÃO DE CRÔNICAS \\ a) Um pouco de história e contexto}

Como bem sabemos, a crônica, na sua concepção contemporânea, pode ser considerada como sendo um gênero híbrido entre o jornalismo e a literatura (mas, também entre a história e o urbanismo). Isto se deve, entre outros motivos, por ter sida concebida inicialmente no jornal, todavia, já no século XX, chegou ao livro. Onde começou? Na Europa, mais especificamente em Paris. Quando, na virada do século XVIII para o XIX. Consta que a primeira crônica foi publicada em 1799 no Journal de Débats. Pela boa recepção por parte dos leitores, logo ultrapassou fronteiras e oceanos, chegando a América do Sul em poucas décadas. Foi assim que, na segunda metade do século XIX, começaram a ser editadas crônicas de autores brasileiros nos principais jornais da época, principalmente na capital, Rio de Janeiro.

Nosso autor maior, Machado de Assis, publicava com bastante frequência suas crônicas em jornais cariocas. Claro que ele não foi o primeiro, nem muito menos o último, mas, sem dúvida, um dos melhores (ou talvez, o melhor daquele tempo). Durante o Século XX, a crônica, que caiu no gosto do brasileiro, foi conquistando leitores por todo o país. Toda grande cidade brasileira tinha cronistas que publicavam nos principais jornais locais.

Sem tira do trono a grandes nomes da crônica carioca, como João do Rio e Rubem Braga, Manaus acolheu e reverencio as crônicas de autores como Josué Cláudio de Souza, Mário Ypiranga Monteiro, Aristófanes Castro, entre outros. Para mais detalhes sobre estes cronistas e sua contribuição à crônica manauara, remeto ao meu artigo "Crônica: do jornalismo à literatura; de Paris a Manaus”, publicado no volume 5, número 9 desta revista, Decifrar, de 2017.

No século XXI, a crônica ganha a difusão digital via Internet. Cronistas amazonenses ilustres, como Milton Hatoum, Tenório Telles, José Ribamar Bessa Freire e José Aldemir de Oliveira (todos professores ou ex-professores da UFAM, seja no curso de Letras-Francês, LetrasPortuguês, História ou Geografia), publicam em jornais, contudo também na Internet (algumas vezes é o próprio jornal que difunde seus artigos nas respectivas páginas WEB, outras, o autor no seu Blog). Porém, além da difusão clássica em jornal e, agora, em Internet, pela qualidade literária da obra destes cronistas, eles passam a publicar, nos últimos anos, livros de crônicas. Seguindo a ordem dos autores já mencionados, temos os livros: Um solitário à espreita: crônicas (2013); Renovação e Viver (2013 e 2014 respectivamente); Essa Manaus que se vai (2012); e, Crônicas de Manaus e Crônicas da minha (C)idade (2011 e 2017 respectivamente). 
Nesta ocasião, escolhemos o último autor (da relação acima) e seu último livro (da relação acima): José Aldemir de Oliveira, Crônicas da minha (C)idade, livro publicado recentemente (há um ano) pela editora Letra Capital do Rio de Janeiro.

\section{b) Escrever crônicas e traduzir crônicas}

A crônica se caracteriza por tratar de assuntos, principalmente, urbanos numa linguagem fluída (mas não necessariamente simples) e não-técnica (evitando conceitos científicos), pois se dedica a um leitor geral (não necessariamente especialista no assunto tratado), porém, leitor de carne e osso. Muitas vezes, o assunto faz parte do dia a dia do cronista e do leitor (e de qualquer outro habitante da cidade em questão, que costuma ser a cidade onde se publica a crônica, que coincide com a cidade de moradia do cronista e do leitor, na maioria das vezes).

Desta forma, nosso autor costuma escrever sobre Manaus e os manauaras. Foi assim que nasceu seu primeiro livro, Crônicas de Manaus, e também o segundo, Crônicas da minha (C)idade, recopilações e reescritura, na maioria dos casos, de crônicas publicadas inicialmente em jornais manauaras ao longo de alguns anos.

Sendo assim, nosso cronista, como todo cronista, costuma descrever um passeio pelo centro da cidade, por um parque, por uma praça; uma visita ao porto ou aeroporto (ou mesmo uma passagem por um dos Terminais de Integração de Manaus); o retorno à rua onde nasceu ou à escola onde estudou. Outro tema soe ser o cidadão comum, contudo que todo mundo conhece, por exemplo, a vendedora de Tacacá, nas noites nunca frias de Manaus; o atendente do Café Regional na feira de domingo, o rapaz do X-caboquinho ou da Tapioca de Tucumã com Queijo Coalho; o senhor da banda de tambaqui, da nossa rua, também aos domingos.

São esses detalhes que todo mundo conhece que o cronista explora, pois bem sabe que, todos gostamos de sentimo-nos parte da história, da crônica. Creio eu que, quanto mais íntima pareça a crônica, mais se identifica o leitor com ela e nela, e, com isto, o relato é elevado a sua mais alta potência, conquistando seu público leitor, de carne e osso.

É aí que começam o problema, nas particularidades do regional, não do cronista, mas do tradutor. Se já é difícil explicar para um guri de Porto Alegre o sabor da Tapioca com Tucumã e Queijo Coalho (que nunca viu nem imagina como seja), ou, para um malandro carioca os ingredientes de um X-caboquinho (além de queijo, um caboquinho? não faz nem ideia do que seja um caboclo); imagine você, caro leitor, como é que vou traduzir esses alimentos que nunca foram vistos por terras de Cervantes, por exemplo, ou de Marcel Proust (outro exemplo)? Complemento cultural: Miguel de Cervantes Saavedra (1547-1616), escritor espanhol, é o autor da obra literária ocidental considerada por muitos especialistas a melhor obra literária de todos 
os tempos, O Quixote; Valentin Louis Georges Eugène Marcel Proust (1871-1922) escritor Frances, é o autor da obra literária considerada por muitos a segunda maior de ocidente, na verdade, trata-se de uma séria de sete livros, Em busca do tempo perdido.

Esse é, talvez, o principal desafio para o tradutor de crônicas: traduzir as particularidades do cotidiano do cidadão de uma cidade distante, bem distante, distância geográfica, distância cultural e distância idiomática. Imagino que seja como explicar a um deficiente visual como é a cor vermelha ou o verde e amarelo da bandeira nacional.

Recentemente li um texto que aborda esta problemática específica. É de um aluno do mestrado da Universidade Autônoma de Barcelona, onde estudam a tradução entre o Chinês, Espanhol e Catalão, "La Extranjerización y la Domesticación de la Traducción Gastronómica según la tipología textual”. Seu autor, Huang Siran, além de trabalhar com textos literários, também analisa textos comerciais (como cartas) e textos turísticos. Para Siran, que considera os critérios de Eugene Nida e Lawrence Venuti muito radicais, a tradução literária tem por objetivo ajudar o intercambio cultural entre duas línguas, logo, seria melhor adotar a estratégia da estrangeirização, desta maneira, é possível conservar os fatores culturais da língua de origem (SIRAN, 2008, p.32).

Uma abordagem mais ampla da questão de escolha entre domesticação e estrangeirização a encontramos em A Tradução Literária do poeta, tradutor e professor da PUC-Rio Paulo Henriques Britto. A segunda parte do livro, que leva como título "A tradução de ficção" (BRITTO, 2012, p.59), tem por objetivo principal responde às questões: que espécie de problemas enfrenta o tradutor? E, que espécie de soluções pode encontrar? Britto propõe uma solução intermediária entre domesticação e estrangeirização, dependendo de: em função do prestígio do autor (estrangeirização), do público-alvo (domesticação) e do meio de divulgação da tradução (se acadêmico, estrangeirização, se popular, domesticação). Como nosso material de trabalho são as crônicas, que priorizam o leitor não especializado, então, certamente nos diria: é mais apropriada a domesticação.

Porém, escrever sobre outra cidade, que não a do autor, principalmente no caso de escrever sobre uma cidade estrangeira, que é visitada pela primeira vez, e, levando em conta que o leitor, de carne e osso, a quem se destina a crônica, provavelmente não conhece esse lugar nem essa língua nem essa cultura, o cronista vai continuar escrevendo como de costume, ou seja, numa linguagem fluída (mas não necessariamente simples), não-técnica (evitando conceitos científicos), e, principalmente, neste caso, em português (língua que tanto o autor quanto o leitor dominam mais do que razoavelmente). 
Este fato simplifica bastante o trabalho do tradutor, pois, provavelmente não se encontrará com palavras de difícil, ou impossível, tradução. Se há algum estranhamento será por parte do leitor da versão do autor (no nosso caso, pode aparecer algum nome em espanhol ou catalão); porém, para o tradutor e para o leitor da tradução não haverá problemas.

O que consideramos interessante é que, o cidadão da urbe objeto da crônica, poderá ler uma crônica de um autor estrangeiro e verificar os pontos de interesse para o olhar de quem vem de fora e tem a primeira impressão sobre a sua cidade. Ou seja, conseguimos viabilizar os dois sentidos da nossa ponte lingüística, literária e cultural.

Sendo assim, passemos aos comentários, em português, dedicados ao leitor do autor, e aos comentários de algumas decisões relevantes da tradução (para quem por tradução se interesse).

\section{COMENTÁRIOS DAS CRÔNICAS E SUAS TRADUÇÕES}

\section{a) Contexto material e formal, o livro}

Para o leitor que ainda não teve a experiência de ler o segundo livro de crônicas de José Aldemir, aqui exponho alguns detalhes (que, evidentemente, de maneira nenhuma substituem o prazer da experiência da leitura).

São 56 crônicas, ou "fragmentos meio escritos, meio falados sobre lugares, gente e..." (OLIVEIRA, 2017, p.6), com um (Quase) Prefácio e uma escrita singular que reflete o olhar atento, interessado e crítico de um cronista que, nas horas vagas, é professor de geografia e aproveita para falar com seus alunos um pouco sobre a cidade, as cidades, minha cidade, a cidade de todos nós. Além de Manaus e outras cidades ou quase cidades, também fala de algumas cidades estrangeiras ou "cidades universais" que o autor visitou e faz questão de dividir com o leitor: Buenos Aires, Lisboa, Paris, e três cidades espanholas: Madri, Salamanca e Barcelona.

Segundo José Aldemir, "para falar das cidades é preciso vivê-las" e "é necessário que delas falemos" (OLIVEIRA, 2017, p.43), ou seja, viver é preciso, viver a e na cidade, pois, como nos ensinou o filósofo: o homem é um animal político (da polis, da cidade, na cidade).

A primeira cidade a ser homenageada pelo cronista é Paris, "Crônica da cidade universal” (p.43-44), cidade que já tinha visitado no ano 2000, cidade modelo para o Ocidente "tanto na arte, como na cultura e no urbanismo" (p.43), cidade berço da crônica urbana.

A quarta cidade é aquela da avenida mais larga que conheço, a cidade dos cafés (como o Tortoni), do obelisco e da Casa Rosada, "Bons Ares" (OLIVEIRA, 2017, p.51-53). A cidade das livrarias (El Ateneo), dos museus e de um tal "Caminito", bem perto de La Bombonera. Todavia, 
"Há outras coisas para serem vista, pois Buenos Aires não é só isso" (p.52). A quinta cidade é "Lisboa" (OLIVEIRA, 2017, p.54-55). "Fui a Lisboa em março, quando os jacarandás ainda dormiam, o céu não estava azul e chovia” (p.55). Quanta poesia numa frase só, para falar da terra que viu nascer o poeta maior, Camões!

No entanto, voltemos algumas páginas, à segunda crônica ou "Crônicas de algumas cidades" (OLIVEIRA, 2017, p.45-47). Curiosidade, inicialmente, o título desta crônica incluía "(Parte II)", pois, a crônica anterior, a primeira, a da cidade da Tour Eiffel, tinha o título de "Crônicas de algumas cidades (Parte I)"; e, a terceira crônica ou "Uma cidade cosmopolita" (OLIVEIRA, 2017, p.48-50) incluía, inicialmente, ao título, “(Parte III - final)”, como podemos verificar no Blog Neopensador (OLIVEIRA, 2014).

Passaremos a seguir às crônicas que selecionamos e seu contexto literário.

\section{b) Contexto literário, as crônicas}

Como a chamada para publicação desta revista, Decifrar, Volume 6, Número 12, é para "Literaturas em língua espanhola", decidimos trabalhar com as duas crônicas do livro Crônicas da minha (c)idade, de José Aldemir de Oliveira que nos falam de três cidades espanholas, escritas em português, e as traduzimos ao espanhol. Nesta parte do artigo, faremos alguns comentários, que consideramos pertinentes, sobre o conteúdo das crônicas.

Inicio justificando o porquê das duas crônicas e não só uma. A "Crônica de algumas cidade" (OLIVEIRA, 2017, p.45-47) começa assim: Três cidades espanholas. E, a partir do segundo parágrafo, nos fala de Madri e Salamanca. A terceira cidade, Barcelona, é objeto da crônica seguinte (p.48-51). Sendo assim, para mantermos a coerência da escrita, consideramos lógico, uma vez que o texto começa fazendo referência a três cidades espanhola, trabalharmos com as duas crônicas.

Estas cidades, para o autor, sintetizam uma ideia do sociólogo, historiador, filósofo da tecno-ciência, filólogo e urbanista estado-unidense Lewis Mumford (1895-1990), segundo a qual, o mundo é uma cidade, a cidade cosmopolita. Título original em inglês: The City in History: Its Origins, Its Transformations, and Its Prospects (1961). Sua tradução ao português já tem várias edições. Curiosa é a história de suas traduções ao espanhol. Logo em 1966, foi traduzida por Enrique Luis Revol e publicada em Buenos Aires pela editora Infinito, com o título "La ciudad en la historia: sus orígenes, transformaciones y perspectivas". Porém, foi só em 2012 que os espanhóis tiveram sua edição (do mesmo tradutor, porém, revisada por Javier Rodríguez Hidalgo), editora Pepitas de Calabaza, de Logroño (norte da Espanha); com uma segunda edição em 2014. Nesta obra, Lewis Mumford faz uma interpretação radical e inovadora sobre a origem 
e a natureza da cidade. Vai desde Egito e Mesopotâmia, passando por Grécia, Roma, prossegue pelas urbes da Idade Média até chegar ao mundo moderno (para ele, o século passado). Contra o pessimismo de um futuro tumultuado e descontrolado tanto das grandes cidades quanto da sociedade urbana, Mumford vislumbra uma ordem que integre a tecnologia, a biologia e as normas sociais.

Entretanto, continuemos com a crônica. José Aldemir justifica o porquê estarem juntas numa mesma crônica Madri e Salamanca: estas cidades conseguem manter o sincronismo entre o antigo e o novo (o passado e o presente). O antigo é o lugar e suas tradições; o novo é o mundo que já faz parte delas, evidenciado pelo seu cosmopolitismo. O cronista nos fala do patrimônio arquitetônico de Madri, suas praças e avenidas, palácios e teatros, museus, vários museus; imponentes construções seculares e modernos conjuntos arquitetônicos. São uns 22 museus que expõem, por exemplo, obras do pós-impressionista francês Paul Cézanne (1839-1906), predecessor do cubismo do século XX, cujo maior representante foi o espanholíssimo Pablo Picasso (1881-1973), que também estava em exposição (ele não, suas obras, claro está).

O olhar do geógrafo urbanista, do professor pesquisador, se detém para contemplar, com a calma que é necessária, praças, parques e jardins, espaços públicos, áreas de "gentrificación" (OLIVEIRA, 2017, p.46). Estranhamento duplo para o leigo leitor que não frequenta as aulas do professor titular da UFAM, pois não conhece os conceitos científicos dos fenômenos urbanísticos, muito menos em espanhol. Confesso que eu tampouco conhecia. Gentrificación em português é gentrificação, do inglês gentrification, derivado de "gentry", que por sua vez deriva do francês arcaico "genterise" que significa "de origem gentil”, isto é, nobre. Gentrificação é um fenômeno urbanístico que afeta, principalmente, as cidades de médio e grande porte, na sua região central ou turística, supervalorização das áreas, que, com o tempo, acaba expulsando aos antigos moradores de baixa renda ou pequenos comerciantes por conta, sobretudo, do alto custo dos imóveis e dos serviços. No entanto, infelizmente, não são só os pequenos comerciantes que são expulsos, em Paris, a loja da Les Puf, editora publicadora de obras acadêmicas-científicas universitária da França, já há alguns anos, teve que fechar sua loja no centro da capital por conta do alto custo do aluguel. Felizmente, na atualidade, conseguira abrir uma nova loja, graças à tecnologia de uma empresa americana, Les Puf imprime na hora o livro que o cliente escolhe, dentro de um enorme catálogo que inclui obras que estavam esgotadas e condenadas ao esquecimento (SAOPAULOSAO, 2016). Em Manaus, tivemos o exemplo da livraria Valer, que teve que fechar as portas da sua livraria no centro da cidade. Quem sabe se o pessoal da Valer compra uma impressora da On Demand books e abre uma loja, mesmo que modesta, para atender 
seu público exigente por obras de qualidade (mas que são comercialmente inviáveis para a logística manauara atual).

Chegamos à metade da crônica, é hora de irmos à segunda cidade. Nada melhor do que uma viagem de trem, Madri-Salamanca, para desfrutar de duas horas de paisagem. Salamanca patrimônio arquitetônico da Idade Média, onde está a terceira universidade mais antigas da Europa e mais antiga da Espanha: Universidade de Salamanca, (em latim, Universitas Studii Salmanticensis). Todavia, no século XIII não havia universidades; se chamava Studium Generale, instituído no ano de 1218 por Alfonso IX de Leão. Foi a primeira instituição educativa européia a receber o título de Universidade, por ato real de Alfonso X o Sábio, a 9 de novembro de 1252, posteriormente ratificada pela licentia ubique docendi de Alexandre IV em 1255. Que inveja! No Brasil, a história das universidades só tem um século, herança da má vontade portuguesa que nem sua língua ensinava aos nativos das colônias, preferia traduzir a bíblia para salvar a alma dos ameríndios, mas não permitia o saber racional para salvar a liberdade dos corpos. A Espanha, pelo contrário, já em 1551 criou a Universidade do México e a do Peru, e em 1586 fundou a Universidade do Equador. Alguns anos depois, foi a vez da Argentina e da Bolívia, e de mais alguns países da América Central. O Chile, antes da independência, tinha três universidades; uma delas, a Universidade de São Felipe, hoje, Universidade do Chile.

Entretanto, continuemos com a crônica, com as igrejas e catedrais de Salamanca, com os monumentos arquitetônicos e seus acervos de arte barroca (século XVII) e sacra (sáculo XVIII), no entanto, a arquitetura moderna, também presente, convive harmoniosamente com a herança do auge do império espanhol. O cronista se surpreende por não ver as marcas negativas da crise européia nas cidades espanholas. Meu caro professor doutor, a Espanha é exemplo vivo de como o saber, o estudo e a pesquisa são bens seculares. Estudar é preciso. Vamos fortalecer nossas universidades.

Contudo, Espanha também tem seu lado mais tropical, que eles chamam mediterrâneo. Barcelona, capital da Catalunha. Todavia, para perseverem como os espanhóis leva a sério o estudo universitário e as pesquisas, lá esteve nosso cronista professor, mas a trabalho, para participar de um congresso de geografia, de Geocrítica. Foi recepcionado por Horacio Capel Sáez (natural de Málaga, cidade do sul da Espanha, na Andaluzia), especialista em Geografia Humana, em geografia urbana, como o professor José Aldemir. Os dos colegas de profissão, com mais alguns outros geógrafos, percorreram ruas e avenidas de Barcelona. Como lá, além do espanhol, falam o catalão, há nomes que nos surpreendem, como o Parc Monjtjuïc, e outros mais familiares que já ouvimos falar, como a Basílica da Sagrada Família e a Fundação Miró, do 
artista plástico Joan Miró i Ferrà, que nasceu em Barcelona no ano de 1893. Miró também foi escultor, gravurista e ceramista, representante do surrealismo.

Aqui, nosso cronista tende bem para o lado geógrafo urbanista, para nossa felicidade. Deste modo podemos ter a descrição da cidade desde um ponto de vista bem interessante, que dificilmente estará num guia turístico. Mais uma vez, se ressalta a harmônica convivência do velho e do novo. Há um pouco de história: a elite da cidade acumulou riqueza vinda da indústria têxtil; no século XIX, a cidade se expande para além das muralhas medievais; ainda é possível “identificar a Barcelona romana, a gótica, a modernista e a contemporânea.” (OLIVEIRA, 2017, p.49). Há destaque para os três grandes arquitetos catalães: Antoni Gaudi (1852-1926), Lluís Domènech i Montaner (1850-1923), e Josep Puig i Cadafalch (1867-1956). Também se fala da arquitetura contemporânea e da bem resolvida convivência dos contrastes, como por exemplo, a Rambla Catalunya, passeio de grandes calçadas onde se pode comprar no comércio popular ou em sofisticadas lojas.

A crônica finaliza com uma reflexão urbanística sobre os desafios da cidade contemporânea, de uma cidade que parece ser uma enciclopédia, uma cidade que bem sabe resolver os conflitos de um mundo cada vez mais urbano e uma cidade cada vez mais mundo, mais todo-mundo.

\section{c) Compartir para aprender}

A respeito dos desafios da tradução dessas duas crônicas, podemos destacar que o autor nos facilita muito o trabalho de tradução pela decisão de manter os nomes próprios no original, em espanhol, tanto nomes de cidades, museus, parques, praças, jardins e até o conceito urbanístico "Gentrificación”, que já comentamos. Os nomes próprios em catalão, os mantivemos assim. Tampouco foi difícil traduzir o início do segundo parágrafo, Madri e Salamanca "cidades que estão e são do mundo" (OLIVEIRA, 2017, p.45), pois o espanhol, assim como o português (e outras línguas ibéricas) têm os verbos ser e estar. Curiosidade: em catalão ficaria mais ou menos assim: “ciutats que estan i són del món”. E em inglês?

Como nunca estive na Espanha, e levando em conta que o tradutor deve conhecer o assunto tratado, e como eu não sou geógrafo nem urbanista nem arquiteto, a Internet me ajudou bastante neste trabalho. Além de consultar dicionários, livros e artigos de teoria da tradução, outros trabalhos de crônica, um amigo espanhol e o próprio autor, recorri ao Google maps para visualizar os locais descritos. Resultou ser muito interessante esta experiência de visita virtual (mapa e fotos de satélite). Pesquisei um pouco sobre todos os autores citados nas crônicas. 
Inclusive, cheguei a ler alguma coisa do trabalho de Lewis Mumford e Horacio Capel Sáez.

Como gosto e pesquiso sobre crônicas, nunca está de mais estudar um pouco de urbanismo.

Vamos, então, as crônicas.

CRÔNICA DE ALGUMAS CIDADES (OLIVEIRA, 2017, p.45-47).

Três cidades espanholas sintetizam a frase de Lewis Munford no livro "A cidade na história": "Este livro começa com a cidade que era simbolicamente o mundo e termina com o mundo que se tornou, em muitos aspectos práticos, uma cidade".

Madrid e Salamanca, pelas semelhanças e diferenças, encerram o sentido de cidades que estão e são do mundo, especialmente pelo sincronismo do antigo e do novo, pela capacidade de articular o lugar e o mundo, conseguindo ao mesmo tempo ser cosmopolitas e não desprezar as tradições.

O patrimônio arquitetônico de Madrid é de tirar o fôlego. A partir da Praça de Cibeles pode-se seguir pela Avenida Gran Via que contém os mais importantes conjuntos de arquitetura modernista. Anda-se um pouco e chega-se à Plaza de Oriente onde se encontram o Palácio e o Teatro Real, imponentes construções do século XVIII. Outra opção são os museus, que valem tanto pelos edifícios quanto pelos acervos e para isso necessita-se de pelo menos dois dias para visitá-los.

O Museu Nacional do Prado, o Centro de Arte Reina Sofia e o Museu ThyssenBornemisza (que estava expondo telas de Cézanne), o Espaço Cultural Fundación Mapfre no mês de abril promoveu uma exposição da obra de Picasso. Na área central de Madrid localizam-se cerca 22 museus com preços bem acessíveis e alguns de graça. É impossível a quem viaja com pressa visitar a todos, todavia os três citados acima são imperdíveis pela possibilidade de se ter acesso a variadas e importantes obras de arte. As chamadas exposições temporárias são excelentes para se ter contato com a obra de artistas específicos e de modo didático.

Outra característica importante da paisagem urbana de Madrid são as praças, os parques e os jardins, espaços cuja adjetivação de públicos se completa na sua inteireza, cujo sentido de gentrificación se observa na prática, pois estão sempre cheios de gente que deles se apropriam como locais da festa. Há o pertencimento: "o lugar é meu e eu sou do lugar".

Para nós de Manaus, que estamos numa cidade literalmente dentro da floresta e não temos um parque urbano, impressiona o conjunto formado pelo Parque del Buen Retiro, Jardim Botânico, Jardines Cecilio Rodriguez e Passeo del Prado, áreas verdes contínuas bem no centro da cidade. Para além desses, há extensas áreas verdes mais afastadas do centro, por exemplo ao redor da Ciudad Universitaria Universidad Complutense de Madrid.

Fui de trem de Madrid para Salamanca: paisagem deslumbrante e que vai mudando à medida que penetra para o interior, com extensas plantações que vão das tonalidades verde profundo ao amarelo brilhante.

Chega-se à cidade que contém um dos maiores patrimônios arquitetônicos da Idade Média. A Universidade de Salamanca é uma das mais antigas do mundo, data do ano de 1218. Há diversos monumentos medievais que se espalham pela cidade onde ainda se vê restos da muralha romana. O Convento de San Esteban dos Dominicanos, um monumento renascentista. As igrejas: a Catedral Velha romana da qual nasce a Catedral Nova que mistura estilo gótico, barroco e renascentista; La Clerecía, igreja barroca erguida pelos jesuítas no século XVIII e que hoje abriga a Universidade Católica. Todos esses monumentos guardam 
no seu interior um dos mais belos e valiosos acervos de obras de arte barrocas do século XVII e de obras sacras do século XVIII.

$\mathrm{O}$ que impressiona em Salamanca é que todo o complexo arquitetônico define o perfil da cidade e se integra ao tecido urbano de modo surpreendente. $\mathrm{O}$ velho e o novo se articulam na Plaza Mayor, extenso pátio quadriculado com saída para várias ruas sempre cheias de gente, sendo o local preferido dos estudantes universitários para apresentarem suas bandas, algumas de qualidade duvidosa. Uma pergunta que fica é: "Por que a crise que atinge a Europa não aparece de modo visível nas duas cidades espanholas?”. Há marcas que não estão nas áreas badaladas visitadas por turistas, onde as vemos de modo explícito, mesmo assim ainda há funcionalidade nos serviços de transporte, e conservação, o que é mais visível a quem passa. Um motorista em Madrid me disse mais ou menos assim: "Acumulamos muita gordura e ainda temos a cidadania e isso não nos tiram tão facilmente".

UMA CIDADE COSMOPOLITA (OLIVEIRA, 2017, p.48-50).

O sentido de multiplicidade lhe cai bem do ponto de vista das experiências urbanísticas e da capacidade de coexistência de espacialidades diversas.

Vi Barcelona quando do Congresso Internacional de Geografia Crítica e tive o privilégio de participar do trabalho de campo com um dos mais importantes geógrafos contemporâneos, Horacio Capel, que nos mostrou parte da cidade, começando pelo Parc de Monjtjuïc até a Basílica da Sagrada Família. Fiz ainda observações pontuais nos intervalos do evento.

O Parc de Monjtjuïc fica em uma montanha entre o mar e a cidade e possibilita visualizar o porto antigo e o recuperado, o passeio de Barceloneta e, ao mesmo tempo, permite lançar o olhar sobre a cidade que se descortina em direção à serra, num traçado urbano em quadrículas característico das fundações romanas, além de visualizar os principais monumentos, velhos e novos, que se misturam às vezes de modo simétrico e outras nem tanto, dando a conformação urbana da cidade.

No topo do Parque está o Castell de Monjtjuïc, fortaleza medieval. Ao norte vemos exemplares representativos da arquitetura contemporânea como a Torre de Comunicações, o Anello Olimpic, o Palácio Sant Jordi e a Fundação Miró. No sopé da montanha há o Palácio Nacional e no rumo da Praça Espanha há um conjunto arquitetônico construído para a Exposição de 1929, símbolo do avanço urbanístico do período, completando-se, no outro lado, com as Arenas de Barcelona, antigas praças de touros, transformadas em templos de consumo moderno.

Barcelona encerra muitos contrastes e talvez seja uma das cidades ou a cidade mais cosmopolita da Europa, pois expressa o modo de vida da elite industrial catalã que esbanjava riqueza oriunda da indústria têxtil e dos negócios nas Américas e buscava no urbanismo avançado demonstrar a capacidade de realização como modelo de domínio econômico e político. Esse processo tornase mais intenso no final do século XIX quando as muralhas medievais foram derrubadas e a cidade se expande sobre áreas de campo.

A cidade mistura diferentes paisagens que mostram a cristalização de tempos no espaço, sendo possível identificar a Barcelona romana, a gótica, a modernista e a contemporânea. São paisagens urbanas expressivas, mas sem dúvida o que marca são as obras de três arquitetos catalães: Antoni Gaudi, com destaque para a Basílica da Sagrada Família e o Palácio Güell; Lluís Domènech i Montaner, com destaque para o Hospital de Sant Pau e o Palácio de La Música Catalã; e finalmente Josep Puig i Cadafalch com as Casas Amatller e Les Punxes e os projetos urbanísticos ligados às grandes avenidas. 
Para o meu olhar que privilegia a paisagem consolidada, os edifícios contemporâneos como a Torre Agbar, o Hotel Santos Porta Fira e o Edifício Media-Tic aparecem como pontos fora da curva, numa paisagem urbana marcada pela harmonia das formas, do mesmo modo como parece exagero a reforma da Basílica da Sagrada Família, uma "monstruosidade urbana" na expressão de Horacio Capel.

Do ponto de vista urbanístico, a melhor demonstração da capacidade de resolver os contrastes em Barcelona é La Rambla Catalunya que começa na Avenida Diagonal e se estende para o sul até o mar no Mirador de Colon. Trata-se de um passeio com amplas calçadas que servem de corredores para a circulação, não de carros, mas de pessoas. Na parte central especialmente na área sul, a partir da Praça de Catalunya, localizam-se pequenos e simples comércios populares de roupas, culinária, flores e mudas de hortaliças. São pequenos quiosques, limpos e bem arrumados, que convivem com lojas sofisticadas e outras nem tanto, numa das áreas de maior concentração de pessoas da cidade.

Para quem se interessa em compreender as cidades, Barcelona é uma enciclopédia para estudos urbanos pelo expressivo patrimônio arquitetônico, pelas experiências urbanísticas e pela capacidade de resolver os contrastes do nosso agora. É possível que nenhuma outra cidade no mundo esteja tão permeada por ideias que apontem soluções urbanas em consonância com os acontecimentos políticos e econômicos contemporâneos.

Identifico, não sem certa perplexidade, que há menos acordo do que havia no final dos anos 90 do século XX sobre qual a melhor maneira de dar sentido, tanto em termos teóricos como práticos, aos desafios que a cidade contemporânea nos colocam.

Nesse sentido, não há certezas e sim muitas dúvidas, pois estamos num processo de transição que ainda não se completou e, como tal, não o compreendemos em sua inteireza.

\section{PROPOSTA DE TRADUÇÃO}

CRÓNICA DE ALGUNAS CIUDADES (OLIVEIRA, 2017, p.45-47).

Tres ciudades españolas sintetizan una frase de Lewis Mumford que está en su libro La ciudad en la historia: "Este libro comienza con la ciudad que era simbólicamente el mundo y termina con el mundo que se ha convertido, en muchos aspectos prácticos, una ciudad”.

Madrid y Salamanca, por las similitudes y diferencias, encierran el sentido de ciudades que están y son del mundo, especialmente por el sincronismo de lo antiguo y de lo nuevo, por la capacidad de articular el lugar y el mundo, logrando al mismo tiempo ser cosmopolitas sin olvidar sus tradiciones.

El patrimonio arquitectónico de Madrid es de pasmar. A partir de la Plaza de Cibeles se puede seguir por la Avenida Gran Vía donde están los más importantes conjuntos de arquitectura modernista. Caminamos un poco más y llegamos a la Plaza de Oriente donde están el Palacio y el Teatro Real, imponentes construcciones del siglo XVIII. Otra opción de visita son los museos, que valen por su arquitectura y por sus acervos, pero debemos reservar al menos dos días para visitarlos, pues son varios. 
Destacamos el Museo Nacional del Prado, el Centro de Arte Reina Sofía y el Museo Thyssen-Bornemisza (que estaba con una exposición de cuadros de Cézanne); también está el Espacio Cultural Fundación Mapfre (que, el mes de abril, promovió una exposición de obras de Picasso). En el centro de Madrid se ubican cerca de 22 museos con entradas baratas o hasta gratis, en algunos casos. Es prácticamente imposible al turista visitarlos todos, sin embargo, los tres citados arriba son imperdibles por la posibilidad de acceso a variadas e importantes obras de arte. Las llamadas exposiciones temporales son excelentes para un contacto con obras de artistas específicos y de una manera didáctica.

Otras características importantes del paisaje urbano de Madrid son sus plazas, sus parques y sus jardines, espacios cuya adjetivación de públicos se completa en su entereza, cuyo sentido de gentrificación se observa en la práctica, pues siempre están llenos de gente, que de ellos se apropian como locales de fiesta. Existe la pertenencia: "el lugar es mío y yo soy del lugar".

Para nosotros de Manaos, que estamos en una ciudad literalmente dentro de la jungla y no tenemos un parque urbano, impresiona el conjunto formado por el Parque del Buen Retiro, Jardín Botánico, Jardines Cecilio Rodríguez y Paseo del Prado, áreas verdes continuas ubicadas en el centro de la ciudad. Además de estos, hay extensas áreas verdes más alejadas del centro, por ejemplo alrededor de la Universidad Complutense de Madrid, que está ubicada en el bario Ciudad Universitaria de Madrid.

Fui en tren desde Madrid hasta Salamanca: paisaje deslumbrante y que va cambiando a medida que pasa por el campo, con extensas plantaciones que van desde tonalidades verdes profundas hasta el amarillo brillante. Llegué a la ciudad que tiene uno de los mayores patrimonios arquitectónicos de la Edad Media. La Universidad de Salamanca es una de las más antiguas del mundo, su historia empieza el año 1218. Hay varios monumentos medievales que se extienden por la ciudad donde aún se ven restos de muralla romana. El Convento de San Esteban de los Dominicos, un monumento renacentista. Las iglesias: la Catedral Vieja romana de la que nace la Catedral Nueva que mezcla estilo gótico, barroco y renacentista; La Clerecía, iglesia barroca erguida por los jesuitas el siglo XVIII y que hoy alberga la Universidad Católica. Todos estos monumentos guardan en su interior uno de los más bellos y valiosos acervos de obras de arte barroca, del siglo XVII, y de obras sacras del siglo XVIII.

Lo que impresiona en Salamanca es que todo el complejo arquitectónico define el perfil de la ciudad y se integra al tejido urbano de modo sorprendente. Lo viejo y lo nuevo se articulan en la Plaza Mayor, extenso patio cuadriculado con salidas para varias calles siempre llenas de 
gente, es el lugar predilecto de los estudiantes universitarios para presentar sus bandas musicales, algunas de ellas de calidad dudosa.

Una pregunta que nos hacemos es: ¿Por qué la crisis que afecta a Europa no aparece de modo visible en las dos ciudades españolas? Hay marcas que no se hallan en las zonas más famosas, visitadas por turistas, donde las vemos de modo explícito, aún así, los servicios de transporte son funcionales, y se preocupan con la conservación, lo que es más visible a quien pasa. Un conductor en Madrid me dijo más o menos esto: "Acumulamos mucha grasa y aún tenemos la ciudadanía y eso no nos lo quitan tan fácilmente".

UNA CIUDAD COSMOPOLITA (OLIVEIRA, 2017, p.48-50).

El sentido de multiplicidad le cae bien desde el punto de vista de las experiencias urbanísticas y de la capacidad de coexistencia de espacialidades diversas.

Estuve en Barcelona para el Congreso Internacional de Geografía Crítica y tuve el privilegio de participar del trabajo de campo con uno de los más importantes geógrafos contemporáneos, Horacio Capel, que nos mostró parte de la ciudad, empezando por el Parc de Monjtjuïc hasta la Basílica de la Sagrada Familia. También hice observaciones propias durante los intermedios del evento.

El Parc de Monjtjuïc se encuentra en una montaña entre el mar y la ciudad y permite ver el puerto antiguo y el recuperado, el paseo marítimo de la Barceloneta y, al mismo tiempo, permite echar una mirada sobre la ciudad que se descortina hacia la sierra, el trazado urbano en cuadrículas característico de las fundaciones romanas, además de visualizar los principales monumentos, viejos y nuevos, que se mezclan a veces de modo simétrico y otras no tanto, dando la conformación urbana de la ciudad.

En la cima del Parque está el Castell de Monjtjuïc, fortaleza medieval. Al norte divisamos ejemplares representativos de la arquitectura contemporánea como la Torre de Comunicaciones, el Anello Olimpic, el Palacio Sant Jordi y la Fundación Miró. Al pie de la montaña está el Palacio Nacional y rumbo a la Plaza España hay un conjunto arquitectónico construido para la Exposición de 1929, símbolo del avance urbanístico del período, y completando, al otro lado, las Arenas de Barcelona, antiguas plazas de toros, transformadas en templos de consumo moderno.

Barcelona encierra muchos contrastes y tal vez sea una de las ciudades o la ciudad más cosmopolita de Europa, pues expresa el modo de vida de la elite industrial catalana que derrochaba su riqueza, oriunda de la industria textil y de los negocios en las Américas, y 
buscaba, en el urbanismo avanzado, demostrar la capacidad de realización como modelo de dominio económico y político. Este proceso queda más intenso a finales del siglo XIX, al derribar las murallas medievales la ciudad se expande sobre áreas de campo.

La ciudad mezcla diferentes paisajes que muestran la cristalización de tiempos en el espacio, es posible identificar la Barcelona romana, la gótica, la modernista y la contemporánea. Son paisajes urbanos expresivos, pero, sin duda, lo que se destaca son las obras de tres arquitectos catalanes: Antoni Gaudí, con destaque para la Basílica de la Sagrada Familia y el Palacio Güell; Lluís Domènech i Montaner, con destaque para el Hospital de Sant Pau y el Palacio de La Música Catalana; y finalmente, Josep Puig i Cadafalch con las Casas Amatller y Les Punxes y los proyectos urbanísticos de las grandes avenidas.

Para mi mirada, que privilegia el paisaje consolidado, los edificios contemporáneos, como la Torre Agbar, el Hotel Santos Porta Fira y el Edificio Media-Tic, parecen ajenos al panorama, de un paisaje urbano marcado por la armonía de las formas, del mismo modo como parece exagerada la reforma de la Basílica de la Sagrada Familia, una "monstruosidad urbana" en la expresión de Horacio Capel.

Desde el punto de vista urbanístico, la mejor demostración de la capacidad de resolver los contrastes en Barcelona es La Rambla, que empieza en la Avenida Diagonal y se extiende hacia el sur hasta el Mirador de Colón, frente al mar. Es un paseo con amplias aceras que sirven de corredores para la circulación, no de coches, sino de personas. En la parte central, especialmente en el área sur, desde la Plaza de Catalunya, se ubican pequeños y simples comercios populares de ropa, culinaria, flores y mudas de hortalizas. Son pequeños quioscos, limpios y ordenados, que conviven con tiendas sofisticadas y otras no tanto, en una de las áreas de más concentración de personas de la ciudad.

Para quien se interesa en comprender las ciudades, Barcelona es una enciclopedia para estudios urbanos por el expresivo patrimonio arquitectónico, por las experiencias urbanísticas y por la capacidad de resolver los contrastes del nuestro ahora. Es posible que ninguna otra ciudad en el mundo esté tan impregnada por ideas que apunte soluciones urbanas en consonancia con los acontecimientos políticos y económicos contemporáneos.

Verifico, no sin cierta perplejidad, que hay menos acuerdo de lo que había a finales de los años 90 del pasado siglo sobre cuál es la mejor manera de dar sentido, tanto en términos teóricos como prácticos, a los desafíos que la ciudad contemporánea nos plantea. Por ello, no hay certezas y sí muchas dudas, pues estamos en un proceso de transición que aún no ha finalizado y, como tal, no lo comprendemos en su totalidad.

\section{CONSIDERAÇÕES FINAIS}


A crônica urbana tem como uma das suas características a linguagem simples quase oral, muitas vezes um diálogo entre um cidadão que escreve e outro que lê. Se entendo a tradução literária como uma reescritura, uma recriação, a tradução de uma crônica deve procurar manter essa característica de uma linguagem quase oral, todavia, mantendo, na medida do possível, o sotaque do autor, não do tradutor. Paulo Henrique Britto afirma que "a boa marca de oralidade é aquela que provoca um efeito de verossimilhança sem chamar demais a atenção para si própria” (BRITTO, 2012, p.101).

Como todo trabalho de tradução, a tradução aqui publicada não passa de uma proposta de tradução, e o trabalho preliminar, um estudo que faço questão de compartilhar, pois estudar é preciso, como também é preciso compartilhar o estudo.

\section{REFERÊNCIAS}

BESSA FREIRE, José Ribamar. Crônicas. Disponível em: <http://www.taquiprati.com.br/>. Acesso em 30 out. 2018.

BRITTO, Paulo Henriques. A Tradução Literária. Rio de Janeiro: Civilização Brasileira, 2012. $160 \mathrm{p}$.

CAPEL, Horacio. Horacio Capel Saez na página da Universidade de Barcelona. Disponível em: 〈http://www.ub.edu/geocrit/capel.htm>. Acesso em 30 out. 2018.

CAPEL, Horacio. La ciudad es el mejor invento humano. (Entrevistado por Equipe bifurcaciones). Disponível em: < http://www.bifurcaciones.cl/003/Capel.htm>. Acesso em 30 out. 2018.

CELEDON, Esteban Reyes. Crônica: do jornalismo à literatura; de Paris a Manaus. Revista Decifrar, vinculada ao Programa de Pós-Graduação em Letras da Universidade Federal do Amazonas, UFAM, Manaus, Volume 5, Número 9, p.1-1, 2017. Disponível em: <http://periodicos.ufam.edu.br/Decifrar/index>. Acesso em 30 de out. 2018.

HATOUM, Milton. Milton Hatoum, página do autor. Disponível em: <http://www.miltonhatoum.com.br/>. Acesso em 30 out. 2018.

Mumford, Lewis. La ciudad en la historia. Sus orígenes, transformaciones y perspectivas. Logroño: Pepitas de Calabaza, 2012, 2014. Tradução de Enrique Luis Revol. Revisão de Javier Rodríguez Hidalgo. Informações disponíveis em: <http://www.pepitas.net/libro/la-ciudad-en-lahistoria>. Acesso em 30.out. 2018.

OLIVEIRA, José Aldemir de. Crônicas de Manaus. 1.ed. Manaus: Editora Valer, 2011.

OLIVEIRA, José Aldemir de. Crônicas da minha (C)idade. 1.ed. Rio de Janeiro: Letra Capital, 2017. $130 \mathrm{p}$. 
OLIVEIRA, José Aldemir de. Uma cidade cosmopolita (Parte III - final). Blog Neopensador. Postado em 28 maio 2014. Disponível em: <http://neopensador.blogspot.com/2014/05/umacidade-cosmopolita-parte-iii-final.html> Acesso em 30 out. 2018.

TELLES, Tenório. Blog do escritor Tenório Teles. Disponível em: <http://www.tenoriotellesblog.wordpress.com>. Acesso em 30 out. 2018.

SAOPAULOSAO. Em Paris, livraria dá adeus a estoque e imprime livros na hora. 29 jul. 2016. Disponível em: <https://saopaulosao.com.br/negocios-criativos/1844-em-paris,-livrariad\%C3\%A1-adeus-a-estoque-e-imprime-livros-na-hora.html\#>. Acesso em 30 out. 2018.

SIRAN, Huang. La Extranjerización y la Domesticación de la Traducción Gastronómica según la tipología textual. Universidad Autónoma de Barcelona. 2008. 35 p. Disponível em: <http://grupsderecerca.uab.cat/txicc/sites/grupsderecerca.uab.cat.txicc/files/Huang\%20Siran_extr anjerizaci\%C3\%B3n_y_domesticaci\%C3\%B3n_de_la_traducii\%C3\%B3n_gastron\%C3\%B3mic a_seg\%C3\%BAn_la_tipologia_textual.pdf>. Acesso em 30 out. 2018. 